\title{
FEMALE VERSUS MALE ENTREPRENEURSHIP WITHIN EUROPE
}

\author{
Ardelean Dorina PhD \\ "Vasile Goldis" Western University of Arad \\ dorina_ardelean@yahoo.com \\ Pribac Loredana PhD \\ "Vasile Goldis" Western University of Arad \\ pribacloredana@yahoo.com
}

(Received June 2015; accepted August 2015)

\begin{abstract}
Entrepreneurship is a topic much debated and analyzed by many research institutions and organizations. In recent years, the total number of entrepreneurs has been increasing significantly, female entrepreneurship being the one that has increased a lot. In this study, we are going to present and analyze the results of studies conducted at European level regarding the comparative evolution of male versus female entrepreneurship. The main conclusion that emerges from the analysis of the results obtained is that the number of women entrepreneurs is almost equal to that of men entrepreneurs in many European countries.
\end{abstract}

Key words: female entrepreneurship, male entrepreneurship, Europe, EU

\section{J.E.L. CODES: 011}

\section{Introduction}

Entrepreneurship is a complex activity that gained importance in the global economy. The rise of female entrepreneurship in economies is a recent phenomenon. Ascher (2012), in her study, highlights the role of female entrepreneurship on the economy, so "women entrepreneurs in transition economies such as Hungary, Poland, Romania and Russia, have a significant impact on the national economies." All over the globe, female entrepreneurship contributes to stability, to well-being among communities, and provides economic opportunities for various disadvantaged groups. (Ascher, 2012)

In this article we analyze the results of various studies at European level and at the level of Romania, regarding the evolution of women entrepreneurs. We want to find an answer to the next question: how important are the women entrepreneurs in a country's economy?

\section{Entrepreneurs in literature}

In literature entrepreneurs are defined in numerous ways, thus some schools saw entrepreneurs as "discoverers", always open to new opportunities; others as 
"assessors" and even as "exploiters" of new opportunities and creators of new combinations. (OECD 2012 p.23)

A general finding in the empirical literature is that entrepreneurs have special features, such as: they risk more in comparison with others; they have the ability to perform many different tasks; the willingness to act independently of an employer; superior skills of understanding, planning and execution; the ability to develop working relationships with co-operators from various professional backgrounds; decision-making power and discernment in prioritizing actions; physical and mental strength to sustain prolonged effort; ability to foresee, mobility and are change-resistant.

In terms of economy, entrepreneurs are those people (business owners) who wish to generate value through the creation or expansion of economic activities, by identifying and exploiting new products, processes or markets.

Turning a business idea into success requires skill, creativity and sound management in pursuing business objectives. Entrepreneurship is the economic concept that combines all these components. In addition, being an entrepreneur involves having the motivation and the capacity to innovate, produce new values and apply own business strategies.

Entrepreneurial activity is seen as a type of work done by men, but in recent years women have been gaining increasingly more confidence in their forces and have become successful women. Currently, women entrepreneurs represent an important number among all entrepreneurs in Europe.

\section{Description of the methodology}

The objective of the study conducted by the European Commission: Statistical Data on Women Entrepreneurs in Europe (2014) was to collect, analyse and systematically present the most recent data on women entrepreneurs in Europa-37. This data will be used to develop evidence-based policy and actions, and thus include number of women entrepreneurs, the type of entrepreneurship, the sectors in which women entrepreneurs are mainly active, age cohort and educational level. The data on women entrepreneurs in 37 countries, which include the $28 \mathrm{EU}$ Member States, Albania, Former Yugoslav Republic of Macedonia, Iceland, Israel, turkey, Liechtenstein, Montenegro, Norway and Serbia. This group of countries is referred to as Europa-37.

If entrepreneurial studies conducted the CEBR - Centre for Entrepreneurship \& Business Research is based on information collected by interviewing a sample representative of the people of Romania. The data set initially it consists of replies interview questionnaire to 852 subjects. To ensure the soundness of the methodology research, were subjected to statistical analysis only those subjects who have provided complete answers to all questions of questionnaire. In this way, 
the number of data available was reduced to 626 subjects in of which $378(60 \%)$ were men and $248(40 \%)$ are women.

Therefore in this study we are going to present the analysis of the statistical data from this two studies conducted on the male versus female entrepreneurship.

3. Aspects regarding women entrepreneurs in Europe: the evolution in time, entrepreneurship as a part-time or a second job, areas of activity, age of entrepreneurs and level of education

Studies on female entrepreneurship are few in number, because female entrepreneurship started holding an important place just a few years ago. The study conducted by the European Commission Statistical Data on Women Entrepreneurs in Europe (2014) shows that in 2012 there were 40.6 million active entrepreneurs in Europe-37, of which 29\% were women (11.6 million). The percentage of women entrepreneurs was slightly higher in the European Union (EU-28), that is $31 \%$ (10.3 million). The percentage of women entrepreneurs from the total number of entrepreneurs varied considerably between countries. With $43 \%$, Liechtenstein had the highest proportion of women entrepreneurs, followed by Latvia (40\%), Lithuania (40\%) and Luxembourg (39\%). With 15\%, Turkey had the lowest percentage followed by Malta (18\%) and Ireland (20\%).

In 2008, as compared to 2012, the percentage of female entrepreneurs was $30 \%$ for Europe-37, thus higher, and for EU-28 it was 28\%, thus less. (Figure no. 1)

According to statistic data, although the number of women active on the labour market is higher than that of men, the number of women entrepreneurs is lower than that of men. The results for female entrepreneurship in neighbouring countries to Romania indicate an equal level of the women entrepreneurs' number in all the 11 countries. (Figure no. 2)

Studies show that Greece is the country with the highest number of men entrepreneurs out of the total of the active male labour force in Europe-37 in 2012 (37\%), and women entrepreneurs represent $24 \%$ of the total of active women. In this respect Romania is ranked among the first countries, positioned ahead of countries such as the Czech Republic, the Netherlands, United Kingdom, Austria, France. In Romania 13\% of the active labour force are female entrepreneurs and $26 \%$ of men are entrepreneurs. In the EU-28 the percentage of entrepreneurs is lower, at $10 \%$ women entrepreneurs and $19 \%$ men entrepreneurs. The change is not significant as far as the percentage in Europe-37 is concerned: we have 10\% women and 20\% men entrepreneurs. (Figure no. 3) 
Ardelean, D.Pribac L., (2015)

Female versus male entrepreneurship within Europe

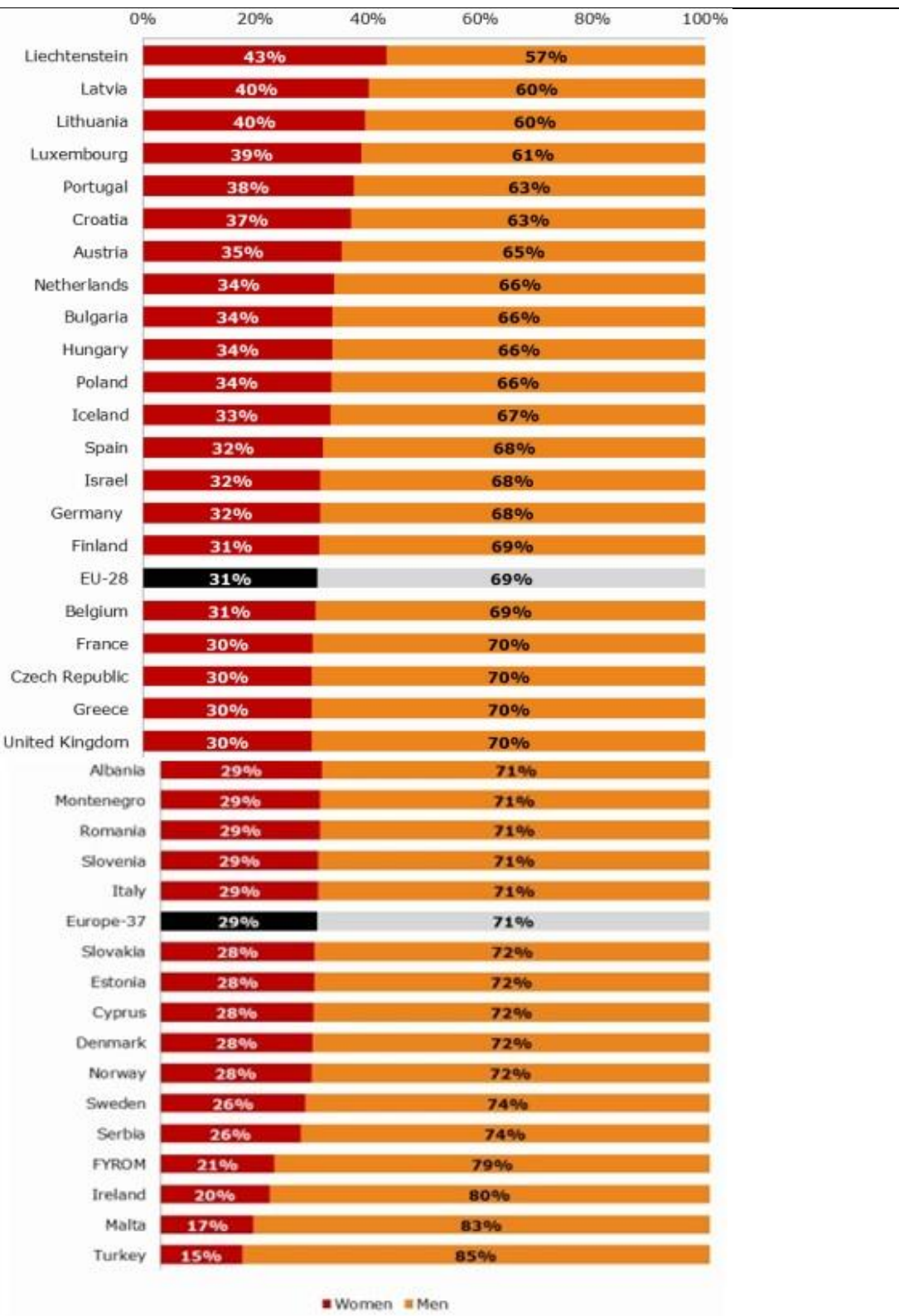

Figure no. 1. Female versus male entrepreneurship within Europe - 2012

Source: European Commission - Statistical Data on Women Entrepreneurs in Europa (2014) 


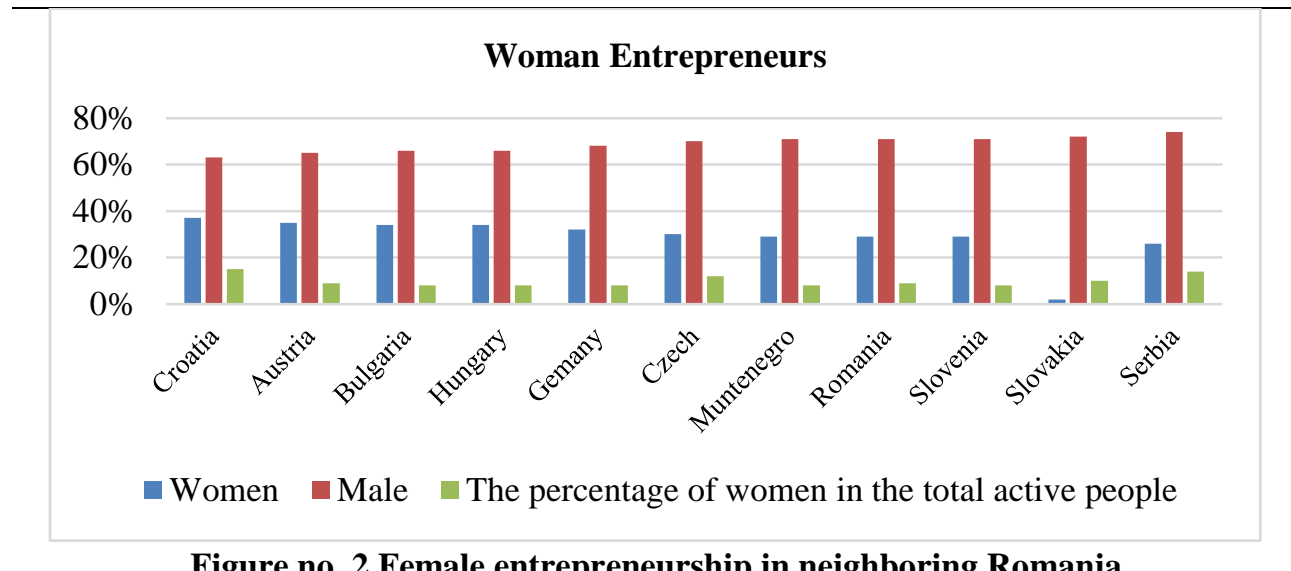

Figure no. 2 Female entrepreneurship in neighboring Romania

Source: European Commission - Statistical Data on Women Entrepreneurs in Europa (2014)

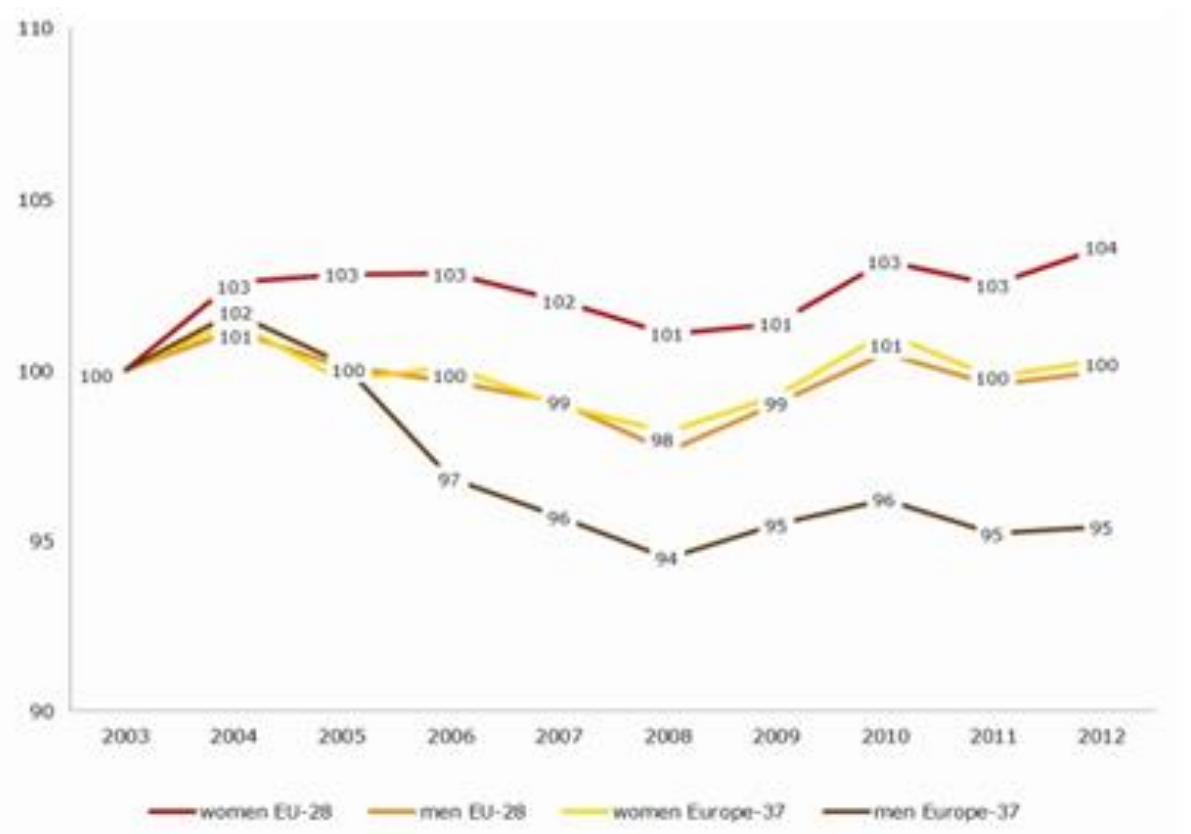

Figure no. 3 Evolution of the number of entrepreneurs in Europe in the period 20032012

Source: European Commission - Statistical Data on Women Entrepreneurs in Europa (2014) 
As one can see in Image 1.3 between 2003-2012 there were periods when the number of entrepreneurs increased, but when the crisis was installed, the number of entrepreneurs began to decrease, and now the trend is upwards. There are various reasons why entrepreneurs choose to work part-time in companies. These reasons may be: another job, household responsibilities, illness or disability, old age or they need time off or time for study.

Entrepreneurship becomes a secondary job when people choose to work in other companies or institutions while working for their own companies only in their spare time.

The most part-time entrepreneurs are in the Netherlands: thus $64 \%$ of women have embraced entrepreneurship, and $25 \%$ of men work part-time. Top two is the UK, which has $54 \%$ part-time women and only $17 \%$ men entrepreneurs. Romania has $31 \%$ women and $26 \%$ men, so in our country we can see a balance between the number of women and men who are part-time entrepreneurs. The last two in the top are Bulgaria (5\% women and $5 \%$ men) and Slovakia (4\% of women and $1 \%$ of men). (European Commission - Statistical Data on Women Entrepreneurs in Europe - 2014)

According to the percentage of people who have one more job besides the job as entrepreneur within Europe-37 in 2012, Norway is the first and Netherlands right below it in the top. The difference between Norway, and Romania, which holds a shameful penultimate position in the top, is of 17.6 percentage points, thus $18.1 \%$ and $0.5 \%$ for women, whereas for men $13.2 \%$ and $1.4 \%$ respectively. In the EU-28 $4.4 \%$ of women and $3.7 \%$ of men have one more job besides being entrepreneurs (Figure no. 4.).

The percentages of solo entrepreneurs were higher for men than for women in most areas; exceptions were health and social activities, other services and education. The percentages of male solo entrepreneurs were highest in constructions, transport, and delivery of services and mining. In all sectors, except other services, the number of men was higher than that of women employers.

The highest percentages of women employers were in activities related to services, education, health and social welfare, as well as arts, entertainment and recreation. The highest percentage of men employers has been in construction.

Special categories of entrepreneurs are farmers, freelancers and individuals. In 2012, there were 5.6 million active farmers in EU-28, of which $30 \%$ were women. Although there were more men than women farmers from all member States, the proportion of women ranged from $42 \%$ in Portugal to $6 \%$ in Ireland. Most farmers were solo entrepreneurs (93\% of women and $88 \%$ men).

Compared with 2008, the number of women freelancers in EU-28 increased by $13 \%$ and the one of male individuals by $13.8 \%$. However, the number of women 
Ardelean, D.Pribac L., (2015)

Female versus male entrepreneurship within Europe

freelancers decreased in: Lithuania, Greece, Estonia, Bulgaria, Hungary, Spain, Cyprus, Italy and Ireland.

In 2012, approximately 4.6 million individuals were active in EU-28, of which 2.1 million were women (45\%). More women than men were active freelancers working in: Romania, Latvia, Lithuania, Hungary, Cyprus, Luxembourg, Finland, Slovakia, Finland, Estonia, Portugal and Bulgaria.

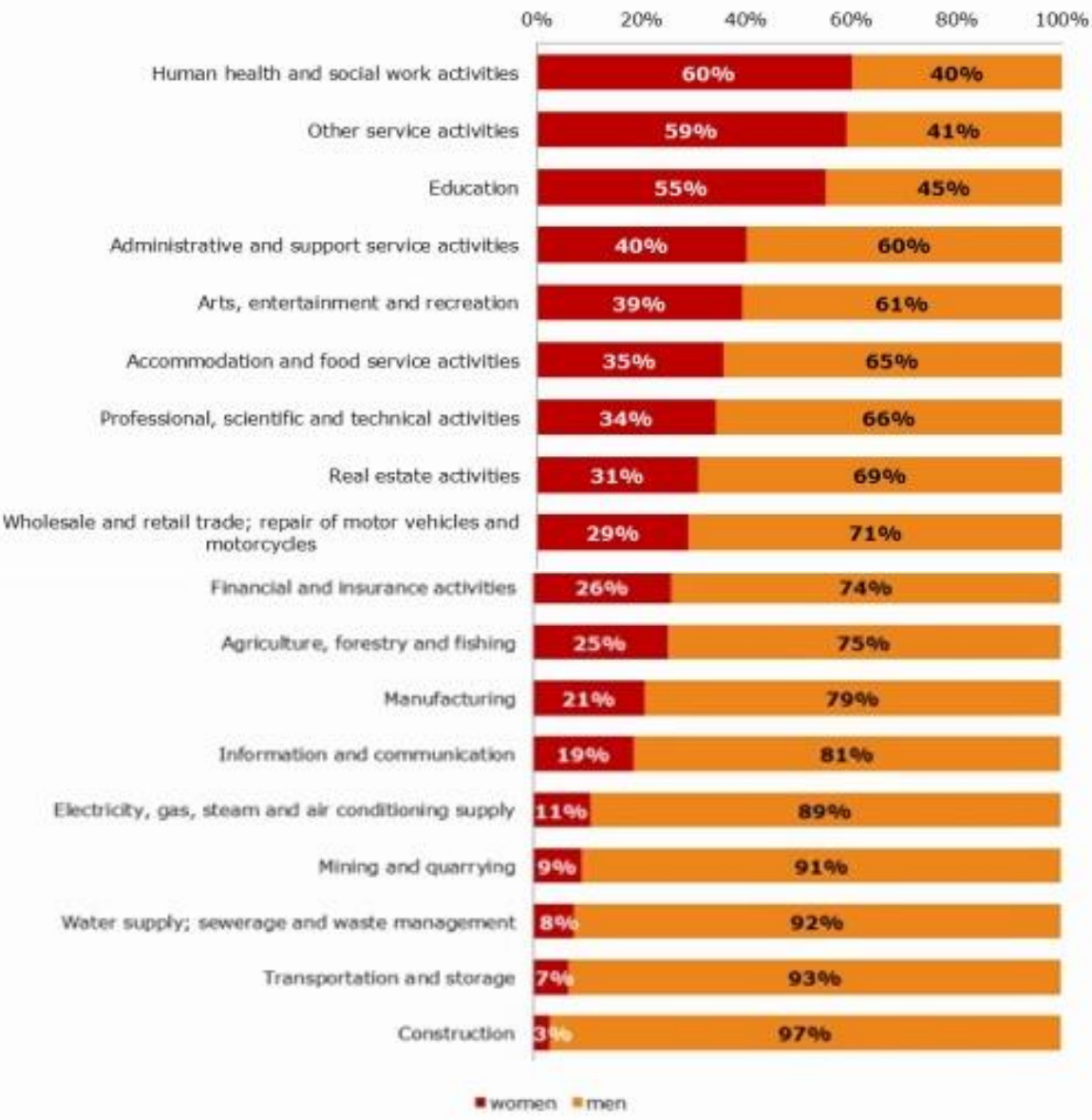

Figure no. 1.4 Sectors in which women were active -2012

Source: European Commission - Statistical Data on Women Entrepreneurs in Europa (2014)

DE GRUYTER

OPEN 


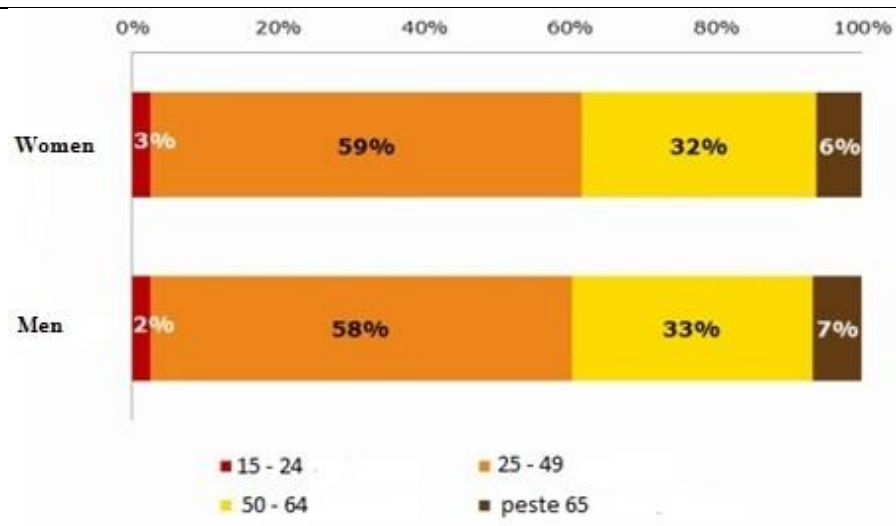

Figure no. 1.5 Age of entrepreneurs

Source: European Commission - Statistical Data on Women Entrepreneurs in Europa (2014)

From the image above we can see that the number of young entrepreneurs is very low, 3\% women and $2 \%$ men, as compared with the number of people who are mature (aged between 25 and 49 years), 59\% women and respectively 58\% men. The percentage of people who have gained relevant experience and are at the end of their careers is $32 \%$ for women and $33 \%$ for men, and those who are over 65 years old and are entrepreneurs are $6 \%$ of women and $7 \%$ of men.

As regards the studies of entrepreneurs in Europe, we can note that Estonia is ranked first, with 2.49 points for women, indicating a higher level of studies, very close to the maximum level ( 3 points) and with men it is 2.36 points. And the level of women entrepreneurs in the Netherlands is close to that of women in Estonia (2.45), and to that of women in Belgium (2.43). The EU-28 level is 2.13 for women (average level) and 2.02 for men (average level). Romania is at the bottom of the classification because the level of education of women entrepreneurs is medium to low (1.53); similar is the case of men (1.61). (European Commission - Statistical Data on Women Entrepreneurs in Europe 2014).

Between 2003-2012 the evolution of women entrepreneurs from all entrepreneurs was an ascending one (for most European countries) and descending for six countries: Finland, Poland, Bulgaria, Montenegro, Croatia and Estonia. For Romania it has been positive showing an increase of $0.5 \%$. In EU-37 the number of female entrepreneurs increased by $3.6 \%$ and in EU-28 by $2.1 \%$.

\section{Female entrepreneurship expands in Romania}

In Romania, the first place in what concerns female entrepreneurship is the county of Galati. According to data for the month of March 2014, two in five 
entrepreneurs in Galati (40.5\%) are women, their number amounting to over 8,600 people. In comparison, in Bucharest, the largest urban concentration in Romania, where there are obviously also most of the businesses, only $35 \%$ of the more than 277,800 individual shareholders are women. (www.economica.net)

A similar situation to that of Galati is in Hunedoara, where the proportion of women among individual shareholders represents 40.27\%. Altogether, in Hunedoara, there are about 7,700 female individual shareholders. A large proportion of female entrepreneurs is found in Tulcea County as well, where $39.76 \%$ of entrepreneurs are female. All in all, in this county having about 267,000 residents there are over 3,700 women shareholders. (www.economica.net)

In contrast, the county where women entrepreneurs have the lowest number, related to the total number of entrepreneurs in that particular county is Harghita. $31 \%$ of entrepreneurs over there are female, out of a total of 15,800 shareholders.

CEBR - Centre for Entrepreneurship \& Business Research conducts studies and research in areas of interest such as entrepreneurship and business. The study shows that the creation of new companies is vital for the economic development of a country, and regardless of country, the study indicated that, while female entrepreneurship is on a growing trend, it is men who set up most entrepreneurial companies.

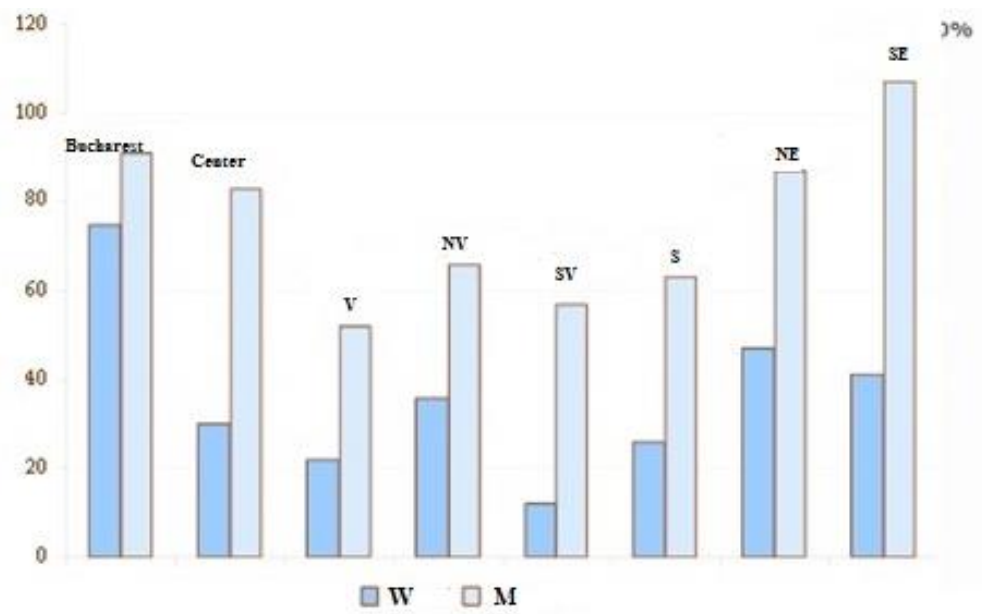

Figure no. 2.1 Female entrepreneurship in Romania

Source: Driga, O., Gonzalez, E. M. L. (2007)

The survey conducted on a sample of 1,547 subjects revealed that while women are involved more in activities preceding the start-up of a business (9.58\%) as compared to $6.53 \%$, yet men dominate the number of those who start actually a 
business. The exception is the capital, Bucharest, where 58\% women vs. $48 \%$ men, prove entrepreneurship skills in creating their own business. Moreover, geographical analysis showed that entrepreneurship is expanding mainly in Bucharest and south-central areas of Romania.

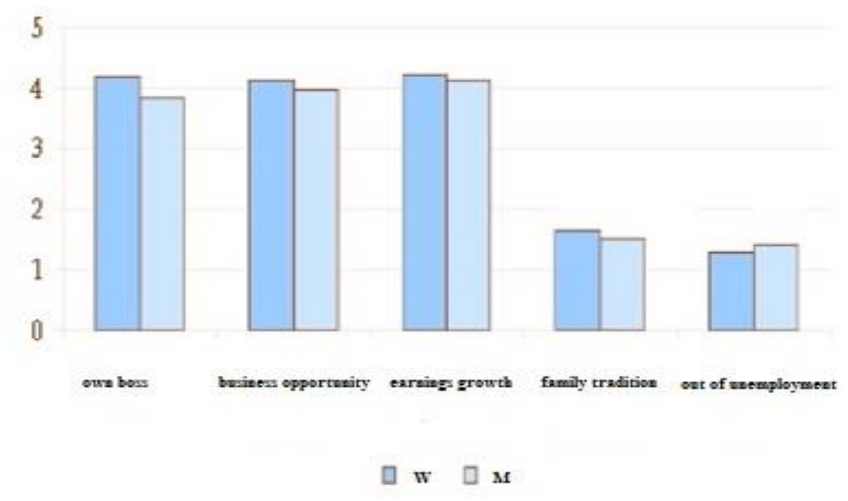

Figure no. 2.2 Entrepreneurial motivation in Romania Source: Driga, O., Gonzalez, E. M. L. (2007)

To get a real image of female entrepreneurs - managers running their own business - in western Romania a study was made within Human Resources Development Operational Programme (2007-2013) "Entrepreneurship and Equality of Chances" - an interregional entrepreneurial school for women - and the results are the following:

- the majority of female respondents (74\%) are married and live in households with 2-4 members, having most of the times 1 or 2 children;

- the average age is 39.04 years;

- $48.4 \%$ are sole owners of the business, while $51.6 \%$ of people own the company together with other people, the co-owners being family members in $85 \%$ of the cases;

- 70\% are employed in their own company;

- over $80 \%$ have university or high school degrees, and $40 \%$ have attended specialization or perfecting courses in different areas, predominantly those related to management and business administration;

- only $29.6 \%$ have a business plan;

- 74.5\% had other previous jobs before getting entrepreneurial experience;

- over $88 \%$ started their own business. (www.faimm.ro)

As entrepreneurs, women in western Romania have been facing numerous obstacles and difficulties, currently growing as compared to the start-up moment of the business: high taxes, bureaucracy, frequent legislative changes, competition, financial difficulties; followed by non-economic obstacles and difficulties: self- 
confidence; combining work and family life; gaining acceptance and respect for people.

\section{Women Entrepreneurship in Arad}

Within the counties, there isn't much information on the number of women entrepreneurs. Arad is one of the counties where a relevant study on female entrepreneurship hasn't been done yet. In other counties, there are studies and data on its evolution.

Available data on the entrepreneurship activity in Arad show that between 19992009 the number of women entrepreneurs has increased from 25,130 to 31,951 (AJOFM Arad).

In 2014 there were 97,000 female employees, of which approximately 60,000 were employed, and the remaining 37,000 are allegedly women carrying an entrepreneurial activity (AJOFM Arad).

\section{Conclusions}

The main conclusions drawn from the results of the studies show that entrepreneurship is an activity that produces the following effects in economy:

- The development of a country is directly proportional to its entrepreneurship development.

- Entrepreneurial activity contributes to the economic growth by generating employment and by the development of innovations.

- Although it has an ascending trend, female entrepreneurship, both globally and in our country is still an underused source of economic growth.

- The presence of entrepreneurial examples in someone's social environment (family, friends) can act as a stimulus for entrepreneurship.

- Another conclusion of a study shows that more people prefer a male boss.

- Statistics show that $62 \%$ of female respondents come from families that have a history in business. The same was true for $59 \%$ of male entrepreneurs.

- Family history weighs more in some countries than in others.

In a future study we will present more detailed results for Arad county, Romania.

\section{Bibliography}

1. Ascher, J. (2012) - Female Entrepreneurship - An Appropriate Response to Gender Discrimination, Journal of Entrepreneurship, Management and Innovation (JEMI), Volume 8, Issue 4, pp. 97-114

2. Driga, O., Gonzalez, E. M. L. (2007) - Antreprenoriatul feminin in Romania: Caracteristici personale si efectul variabilelor socio-culturale, ISSN 1843-4428 
3. Niethammer-Odebrecht, C. (2013) - Women, Entrepreneurship and the Opportunity to Promote Development and Business, The Brookings Blum Roundtable Policy Briefs

4. Robb, A., Coleman, S., Stangler, D. (2014) - Sources of Economic Hope: Women's Entrepreneurship, The Ewing Marion Kauffman Foundation

5. Santo, M. (2015) Women's Economic Empowerment both Nationally and Internationally - House of Lords

http://researchbriefings.parliament.uk/ResearchBriefing/Summary/LLN-2015006\#fullreport

6. *** AJOFM Arad www.arad.anofm.ro

7. *** Asociatia Femeilor Antreprenor din Romania www.afar.ro

8. *** Judetul cu cele mai multe femei patron din Romania (2014)

http://www.economica.net/judetul-cu-cele-mai-multe-femei-patron_79600.html

9. *** CEBR - Centre for Entrepreneurship \& Business Research www.kfacts.ia.ro

10. *** European Commission - Statistical Data on Women Entrepreneurs in Europa (2014)

11. *** ILO (2014) - Women's Entrepreneurship Development

12. *** OECD (2012) - Measuring Women Entrepreneurship in Entrepreneurship at a Glance 2012, OECD Publishing

13. *** OECD (2013) - Women Entrepreneurs in the OECD http://www.oecdilibrary.org/docserver/download/5k43bvtkmb8v.pdf?expires=1433233212\&id=id\& accname $=$ guest $\&$ checksum $=75841793$ D5532C5A0521CEC8C2E0ED78

14. ***POSDRU 2007-2013 (2011) „Antreprenoriatul si egalitatea de sanse. Un model interregional de scoala antreprenoriala pentru femei" www.faimm.ro 